\title{
Comparing handline and trolling fishing methods in the recreational pelagic fishery in the Gulf of Oman
}

\author{
Morteza Eighani ${ }^{1}$, Seyed Yousef Paighambari ${ }^{1}$, Shannon M. Bayse ${ }^{2}$ \\ ${ }^{1}$ Fisheries Department, Gorgan University of Agricultural Science and Natural Resources, Gorgan, Iran. \\ (ME) E-mail: morteza_eighani@yahoo.com. ORCID iD: https://orcid.org/0000-0002-6830-3644 \\ (SYP) (Corresponding author) E-mail: sypaighambari@gau.ac.ir. ORCID iD: https://orcid.org/0000-0002-8893-9308 \\ ${ }^{2}$ Fisheries and Marine Institute, Memorial University of Newfoundland, 155 Ridge Road, St. John's, NL A1C 5R3, \\ Canada. \\ (SMB) E-mail: Shannon.bayse@mi.mun.ca. ORCID iD: https://orcid.org/0000-0002-0343-4053
}

\begin{abstract}
Summary: The choice of fishing gear and catching strategy should be taken into consideration in the management of fish stocks. Here, paired fishing trials in a pelagic recreational fishery compared the catch composition, catch rate and size selectivity between handline and trolling fishing methods in Iranian coastal waters of the Gulf of Oman. Total catch rate was 1.06 fish $\mathrm{hr}^{-1} \mathrm{vs} 0.88 \mathrm{fish} \mathrm{hr}^{-1}$ for handline and trolling, respectively, a 17\% difference which was significant $(\mathrm{p}<0.05)$. Generally, the handline method captured more fish than trolling for most species, but size selectivity tended to be species-specific per gear type. The handline fishing method captured larger talang queenfish (Scomberoides commersonnianus), while trolling captured larger narrow-barred Spanish mackerel (Scomberomorus commerson), pickhandle barracuda (Sphyraena jello) and Indian threadfish (Alectis indicus). Technical measures, such as gear restrictions, could be applied to recreational pelagic fisheries management in the Gulf of Oman. Such measures could improve species-specific exploitation patterns.
\end{abstract}

Keywords: handline; trolling; catch efficiency; selectivity; recreational fishing; Gulf of Oman.

Estudio comparativo de pesca pelágica recreativa entre las artes de línea de mano y curricán en el golfo de Omán, Irán

Resumen: La selección del equipo de pesca y la estrategia de captura deben ser consideradas en la gestión de stocks pesqueros. En el presente estudio se muestran resultados de tipos, tasas y selectividad de talla de las capturas en una experiencia comparativa de artes de pesca en aguas costeras del golfo de Omán, Irán. Las tasas de captura finales para las artes de línea de mano y curricán fueron de 1.06 y 0.88 peces $^{-1}$ respectivamente, mostrando un significativo $17 \%$ de diferencia entre ambas ( $\mathrm{p}<0.05)$. Por lo general, el arte de línea de mano resultó en una mayor tasa de captura multiespecífica, sin embargo la selectividad de talla se observó arte-dependiente. En el arte de línea de mano se observaron capturas de mayor talla para la especie "talag queenfish" (Scomberoides commersonnianus), mientras que para el curricán fueron la caballa o verdel (Scomberomorus commerson), barracuda (Sphyraena jello), e "Indian threadfish" (Alectis indicus). En conclusión, la implementación de medidas técnicas, como restricciones en las artes de pesca, podrían ser aplicadas en la regulación de la normativa de pesca recreativa para la gestión general pesquera con el objetivo de la mejora en los patrones de explotación especie-específica del golfo de Omán.

Palabras clave: línea de mano; curricán; eficiencia de captura; selectividad de talla; pesca recreativa; golfo de Omán.

Citation/Como citar este artículo: Eighani M., Paighambari S.Y., Bayse S.M. 2019. Comparing handline and trolling fishing methods in the recreational pelagic fishery in the Gulf of Oman. Sci. Mar. 83(3): 000-000. https://doi.org/10.3989/ scimar.04864.10A

Editor: J. Lloret.

Received: September 25, 2018. Accepted: May 17, 2019. Published: June 17, 2019.

Copyright: (c) 2019 CSIC. This is an open-access article distributed under the terms of the Creative Commons Attribution 4.0 International (CC BY 4.0) License. 


\section{INTRODUCTION}

Fishing has been a major source of food for centuries and also an important recreational activity for decades in many countries (Valdimarsson and James 2001, Welcomme 2001). Small-scale fisheries contribute about half of global fish catches and provide extensive employment to approximately 37 million people, of whom around $90 \%$ are in Asia (FAO 2016). Coastal fisheries supply daily food and serve as one of the few sources of income for many coastal populations in the Gulf of Oman region. In southeastern Iran, much of the fish consumed in coastal rural areas is caught by artisanal or subsistence fishers. Additionally, some catch is sold, which significantly contributes to the livelihoods of these small-scale commercial fishers. Many people who rely on fisheries are in a lower income group and their livelihoods depend directly on the sustainability of the fishing industry. Today, awareness of the impact recreational fisheries have on fish populations has increased, and it is recognized that estimating recreational fishing effort and catch is necessary for sustainable fisheries management (McPhee et al. 2002, Jones and Pollock 2012).

Small-scale fishing vessels in the Gulf of Oman have increased in both number and efficiency, increasing from 857 to 2019 small handline and trolling vessels between 2011 and 2015 (IFO 2017). This has heightened the conflicts among various fisheries and user groups and intensified competition for use of limited resources. This significant temporal expansion of the fishery has likely increased the fishery's impact on pelagic species populations. A dramatic decrease in pelagic species landings over the past decade, exacerbated by a lack of regulations, has raised concerns about the sustainability of this fishery (Al-Hosni and Siddeek 1999, Niamaimandi et al. 2015). Despite the seriousness of this issue, studies on pelagic fish captures by fishing gears in the Gulf of Oman are scarce (Paighambari and Eighani 2017) and entirely missing for the Iranian coastal waters. This has drawn attention from the government regarding the appropriate management for consistent production and use of environmentally friendly fishing gear. In the Gulf of Oman recreational fishery, there are no management regulations or size limitations, and fish stocks could potentially become depleted due to long-term unsustainable harvesting.

Artisanal fisheries for pelagic species occur throughout coastal waters in southeastern Iran within the Gulf of Oman, and catches include the Indian threadfish (Alectis indicus), the narrow-barred Spanish mackerel (Scomberomorus commerson), the pickhandle barracuda (Sphyraena jello) and the talang queenfish (Scomberoides commersonnianus). These species account for more than $90 \%$ of the annual production of the fishery (approximately $10000 \mathrm{t}$ ) (Herrmann et al. 2018). These pelagic species are targeted using several types of small-scale fishing gears that include handline and trolling. Handline and trolling gears are somewhat species-selective; the selectivity of such line gears is affected by the fishing strategy used with respect to the vertical and horizontal distribution of the target species (Løkkeborg and Bjordal 1992). Previous studies indicated that the handline method has low size selectivity for some pelagic species in the Persian Gulf recreational fishery (Paighambari and Eighani 2017). The catching processes of trolling and handline are different. Trolling is a towed gear, while handline is a static gear. Although not aimed at improving the selectivity or efficiency of particular gears, many other studies have compared alternative and/or competing fishing methods, including longlines versus gillnets (e.g. Santos et al. 2002, Stergiou et al. 2002, Erzini et al. 2003) and longlines versus trawls (e.g. Hovgård and Riget 1992, Otway et al. 1996, Fauconnet et al. 2015). In most cases, these comparisons were done to reduce sampling bias and improve resource estimates. An indirect benefit, however, it is that these studies provided information on the relative selection between different gears and methods. Generally, these studies conclude that static gears are typically more size- and species-selective than towed gears (e.g. Løkkeborg and Bjordal 1992, Huse et al. 1999, Stergiou et al. 2002). Additionally, we hypothesized that a more mobile species would have a higher chance of encountering the fishing gear than a less mobile one. The potential benefits of such a lateral approach towards improving the selectivity of problematic gears are explored in the following experimental case study comparing passive and towed artisanal fishing gears for pelagic species in Iranian coastal waters of the Gulf of Oman.

The main objective of this study was to compare catch rates and size selectivity among different common fishing methods (handline and trolling) for catching pelagic species in the Iranian coastal waters of the Gulf of Oman. Differences in catch composition, catch rate, and size selectivity between capture methods can be used to determine the type of fishing approach recommended for Gulf of Oman recreational fishers to implement sustainable fishing practices.

\section{MATERIALS AND METHODS}

\section{Study area}

Data were collected on board artisanal fishing vessels in the Iranian coastal waters of the Gulf of Oman, Chabahar region $\left(60^{\circ} 44^{\prime} \mathrm{E}\right.$ and $\left.25^{\circ} 16^{\prime} \mathrm{N}\right)$, between October and November 2017 (Fig. 1). Fishing took place approximately $15 \mathrm{~km}$ from the coast at depths ranging from 5 to $15 \mathrm{~m}$.

\section{Gear description}

Handline was defined as a simple form of hookand-line gear which consisted of a hand-held single line with rod, weight, and one or more hooks spaced along the far end of the line (Eighani et al. 2018). Fishers deployed a handline with a baited hook over the side of the boat, and once a fish was hooked, immediately hauled it in by hand. In this experiment, the handline consisted of a 30-m monofilament mainline with a diameter of $1.5 \mathrm{~mm}$. The weight of the lead (sinker) at the end of the fishing line was $2 \mathrm{~kg}$. 


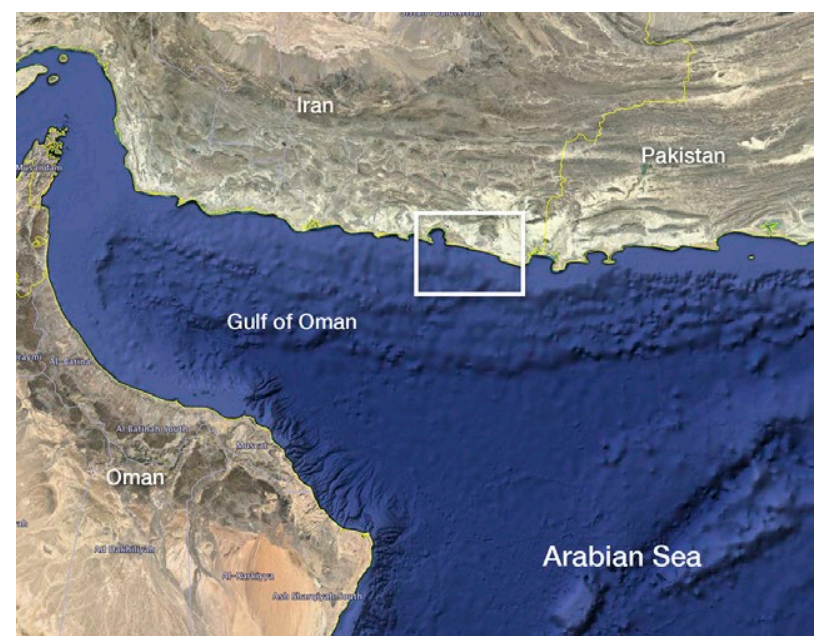

Fig. 1. - Map of the study area in the Iranian coastal waters of Gulf of Oman, Chabahar region (in the box).

Trolling refers to the towing of a hook with artificial lures or natural baits near the water's surface from a moving boat (NRC 1988, Mohri et al. 2017). It is an active fishing method whereby a line with hooks is attached behind the vessel and trolled at a specific speed, so that the hooks reach a desired depth where the target species is expected to be present; the fish are attracted to the bait and move towards the gear. The lengths of the towing rope and branch line and their interval are dependent on the target species, distribution density and swimming depth. Here, polyamide line of $3 \mathrm{~mm}$ diameter was used as the main line. The length of line was $30 \mathrm{~m}$. No.4/0 corkscrew heavy-duty brass swivels were used. The dorsal end of the swivel was attached to one end of the main line permanently by splicing. On arrival at the fishing ground, the line was shot into the water. When the shooting operations were over, the boat was propelled at a speed of 3 to 5 knots. Once a fish was hooked, it was hauled in by hand. After the removal of the fish, the line was shot once again, and the same pattern was repeated.

\section{Data collection}

Trip duration and total length of each individual caught were collected by onboard fishery observers using standard forms and procedures. The same hook and bait size were used in all fishing operations. Mustad 6/0 J-hooks were used, as is common in the fishery. Whole sind sardinella (Sardinella sindensis) $(14 \pm 3.2 \mathrm{~cm}$; mean \pm standard deviation) were used as bait. Fishing trips were carried out daily from dawn to dusk. The duration of each trip varied between 5 and $13 \mathrm{~h}$. Gears were used in separate vessels and paired, i.e. both gears were fished simultaneously enabling a paired comparison. For all trips, experiments were carried out by the same samplers for each vessel. The same two wooden 7 -m-long boats with $30 \mathrm{hp}$ engines, as typical for the commercial fishery, were used for the daily fishing trips. All fishers fished in the same location during trials. All characteristics of the fishing gear and practices (e.g. hook placement, deployed number of hooks of each style per set, bait size and type and setting time) were standardized throughout the study.

\section{Statistical analysis}

For the following analyses, a replicate was considered as one day of fishing, which produced a comparative pair between gear types. Fish catch-atlength was analysed by comparing the proportion of the catch between trolling and handline gears at each length class following the methods of Holst and Revill (2009). This analysis uses polynomial generalized linear mixed models (GLMMs) to fit curves of the expected proportions of catch length using the MASS package (Venables and Ripley 2002) of R (R Development Core Team 2009). This method uses low-order polynomial approximations (cubic, quadratic, linear, or constant) to fit the proportions at length retained by each fishing method. Paired analysis enables conditions between gears to be as close as possible; however, variation between pairs can still exist and be included in the model estimates as a random effect. Therefore, "pair" was considered a random effect in our model and the fixed effect was "length". The model used a binomial GLMM with a logit link function to fit each polynomial followed by subsequent reductions of terms until all showed statistical significance $(\mathrm{p}<0.05)$ based on Wald $t$-tests, with removal of one term at a time to determine the best model fit (for additional details see Holst and Revill 2009). A proportion of 0.5 indicated no difference in catch between the two gears for the specific length. A proportion of 0.75 indicated that $75 \%$ of fish at a specific length were caught by trolling and $25 \%$ by handline. SIMPER analysis (cut off $90 \%$ ) was used to identify the important taxa that contributed to overall dissimilarity between gears.

Catches of the number of individuals between paired handline and trolling fishing methods were analysed with linear mixed models (Bayse et al. 2016, 2017). The dependent variable was "Catch rate", and was standardized as the number of fish caught per hour. Additionally, catch rate data was non-normal, and thus was log transformed to meet the assumptions underlying liner modelling. For each model the independent variable was "Gear", which was a categorical variable labelled as either handline or trolling, enabling the comparison of catch rates between the different gear types. The random effect was "pair". Since this was a paired analysis, enabling as close to the same conditions between gears as possible, variation between pairs can still exist and be included in the model estimate as a random effect. Models were fitted using the lme 4 package of the $\mathrm{R}$ statistical software (Bates et al. 2013, R Development Core Team 2009). Models of each gear type were compared with likelihood ratio tests, and used the $\chi^{2}$ test statistic to determine the difference in deviance $\mathrm{d}_{\mathrm{o}}-\mathrm{d}_{\mathrm{a}}$, where $\mathrm{d}_{\mathrm{a}}$ is the deviance of the full model and $\mathrm{d}_{\mathrm{o}}$ is the deviance of the constrained model, to an $\alpha$ of 0.05 (Bates et al. 2013). 
Table 1. - Generalized linear mixed model parameters for Indian threadfish, narrow-barred Spanish mackerel, pickhandle barracuda and talang queenfish in which model and parameter refers to the chosen model [constant $\left(\beta_{0}\right)$, linear $\left(\beta_{1}\right)$, quadratic $\left(\beta_{2}\right)$, or cubic $\left.\left(\beta_{3}\right)\right]$. Estimate is the value of the slope or intercept; SE, standard error of the estimate; and df, degrees of freedom.

\begin{tabular}{|c|c|c|c|c|c|c|c|}
\hline Species & Model & Parameter & Estimate & SE & df & t-value & $\mathrm{p}$-value \\
\hline A. indicus & Linear & $\begin{array}{l}\beta_{1} \\
\beta_{0}\end{array}$ & $\begin{array}{l}24.792 \\
25.263\end{array}$ & $\begin{array}{l}0.068 \\
4.392\end{array}$ & $\begin{array}{l}46 \\
46\end{array}$ & $\begin{array}{c}-6.909 \\
5.753\end{array}$ & $\begin{array}{l}<0.001 \\
<0.001\end{array}$ \\
\hline S. commerson & Quadratic & $\begin{array}{l}\beta_{2} \\
\beta_{1} \\
\beta_{0}\end{array}$ & $\begin{array}{l}36.385 \\
36.600 \\
36.381\end{array}$ & $\begin{array}{c}0.001 \\
0.237 \\
11.022\end{array}$ & $\begin{array}{l}93 \\
93 \\
93\end{array}$ & $\begin{array}{c}3.316 \\
-3.294 \\
3.301\end{array}$ & $\begin{array}{l}0.001 \\
0.001 \\
0.001\end{array}$ \\
\hline S. jello & Linear & $\begin{array}{l}\beta_{1} \\
\beta_{0}\end{array}$ & $\begin{array}{l}-3.724 \\
-3.788\end{array}$ & $\begin{array}{l}0.016 \\
1.338\end{array}$ & $\begin{array}{l}137 \\
137\end{array}$ & $\begin{array}{c}4.072 \\
-2.832\end{array}$ & $\begin{array}{c}<0.001 \\
0.005\end{array}$ \\
\hline S. commersonnianus & Linear & $\begin{array}{l}\beta_{1} \\
\beta_{0}\end{array}$ & $\begin{array}{l}-7.718 \\
-7.863\end{array}$ & $\begin{array}{l}0.028 \\
1.725\end{array}$ & $\begin{array}{l}73 \\
73\end{array}$ & $\begin{array}{c}5.135 \\
-4.559\end{array}$ & $\begin{array}{l}<0.001 \\
<0.001\end{array}$ \\
\hline
\end{tabular}
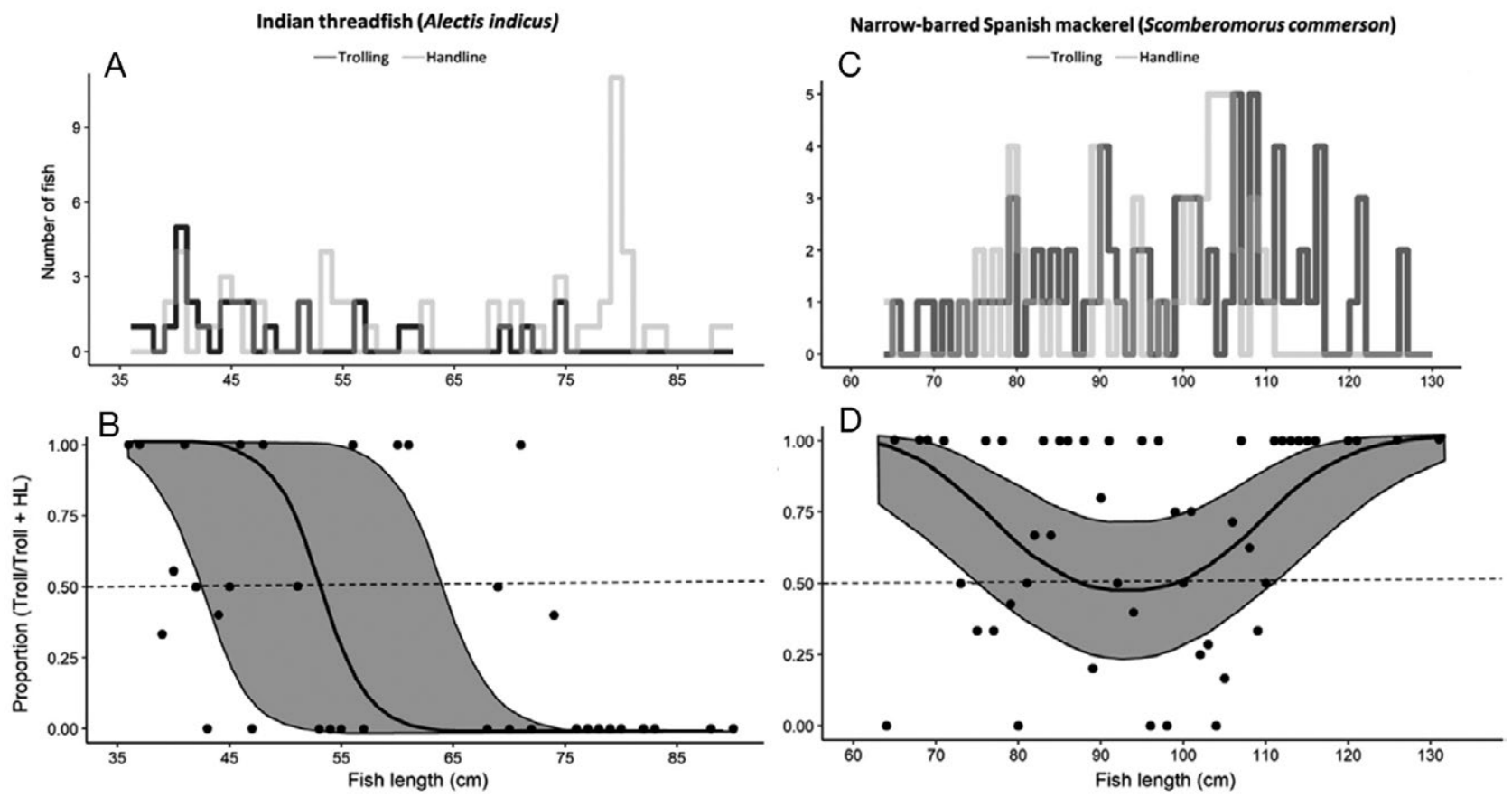

Fig. 2. - Length frequency of Indian threadfish (A) and narrow-barred Spanish mackerel (C) from trolling (solid line) and handline (dashed line) gear. Catch proportions [trolling/(trolling + handline)] between gears (circles) and GLMM-modelled proportions of catch-at-length by trolling and handline gear for Indian threadfish (B) and narrow-barred Spanish mackerel (D). Predicted mean is the black line and grey areas are the $95 \%$ confidence intervals. A value of 0.5 indicates an even split between gears for the specific length; a value of 0.75 indicates that $75 \%$ of fish caught at this length were captured by trolling and $25 \%$ by handline gear.

\section{RESULTS}

In total, 42 experimental handline trips were made, totalling 288 fishing hours, and captured 305 specimens. All captured species included greater lizardfish (Saurida tumbil), Indian threadfish (Alectis indicus), narrow-barred Spanish mackerel (Scomberomorus commerson), obtuse barracuda (Sphyraena obtusata), pickhandle barracuda (Sphyraena jello) and talang queenfish (Scomberoides commersonnianus). For experimental trolling, 307 specimens were captured for 42 trips and 354 fishing hours. The main species captured were Indian threadfish, narrow-barred Spanish mackerel and obtuse barracuda (74\% of catch) for handline gear, and pickhandle barracuda, narrow-barred Spanish mackerel and talang queenfish (87.6\% of catch) for trolling.

Length analysis was carried out for species that had enough individuals captured across a reasonable range of lengths. For Indian threadfish, catch-at-length de- creased linearly where smaller fish were captured more by trolling $(<45 \mathrm{~cm})$ and larger fish by trolling $(>65$ cm; Table 1; Fig. 2). Narrow-barred Spanish mackerel catch-at-length had a quadratic relationship with smaller fish $(<75 \mathrm{~cm})$ and larger fish $(>110 \mathrm{~cm})$ captured more often via trolling, and sizes between these lengths showed no difference between gears (Table 1; Fig. 2). Large pickhandle barracuda $(>90 \mathrm{~cm})$ were captured by trolling, with an increasing linear relationship (Table 1; Fig. 3). Talang queenfish catch-at-length results showed a linear relationship in which smaller fish were captured by handlining $(<40 \mathrm{~cm})$ and larger fish by trolling ( $>65 \mathrm{~cm}$; Table 1; Fig. 3 ).

Indian threadfish and obtuse barracuda were captured more often by handline gear, which had catches $61.9 \%$ and $66.7 \%$ higher than trolling, respectively (Table 2). For other species, the catch rate was similar between gears and showed no significant differences ( $>0.05$; Table 2). 

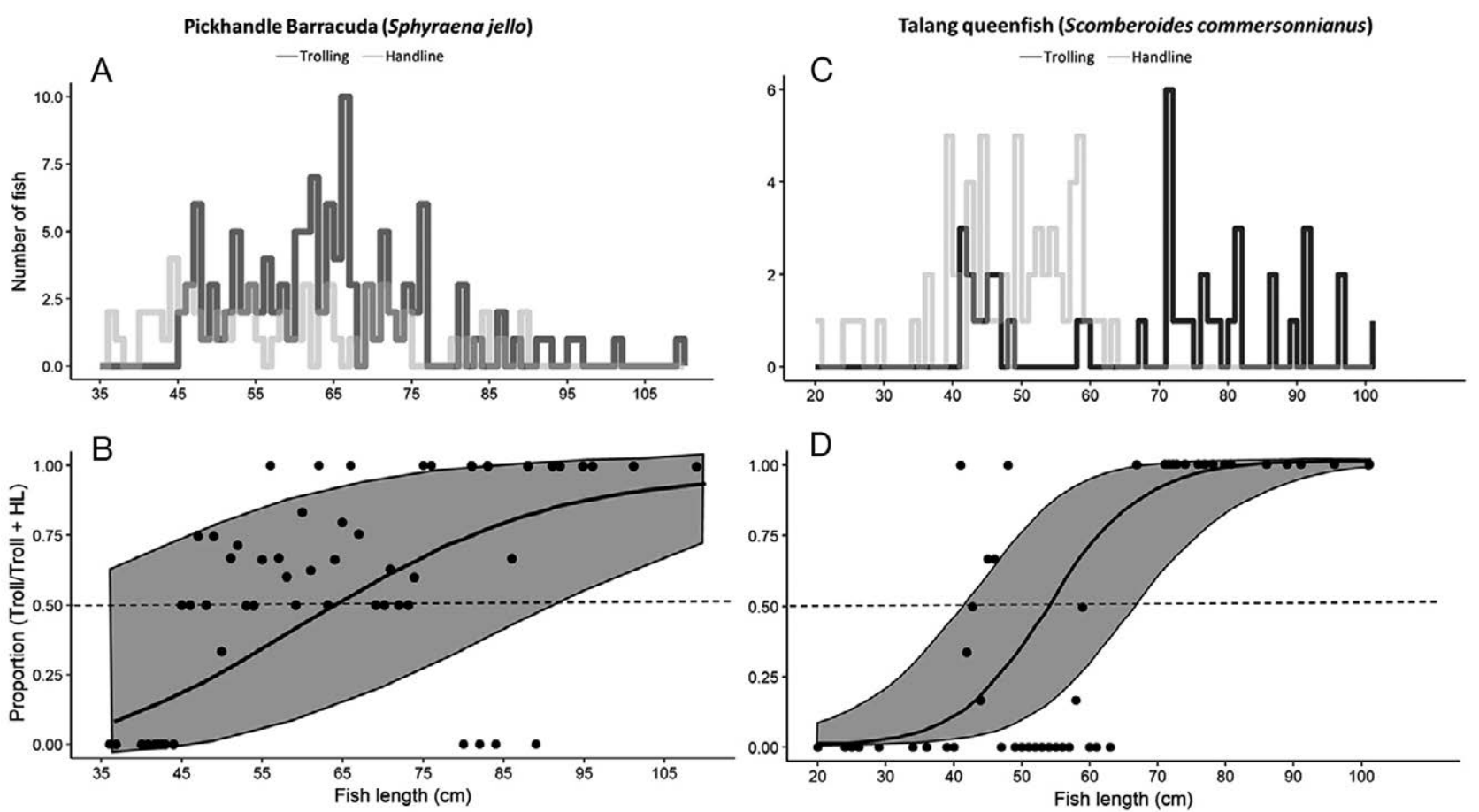

Fig. 3. - Length frequency of pickhandle barracuda (A) and talang queenfish (C) from trolling (solid line) and handline (dashed line) gear. Catch proportions [trolling/(trolling + handline)] between gears (circles) and GLMM-modelled proportions of catch-at-length by trolling and handline gear for pickhandle barracuda (B) and talang queenfish (D). Predicted mean is the black line and grey areas are the $95 \%$ confidence intervals. A value of 0.5 indicates an even split between gears for the specific length; a value of 0.75 indicates that $75 \%$ of fish caught at this length were captured by trolling and $25 \%$ by handline gear.

Table 2. - Observed mean catch rate (fish $\mathrm{hr}^{-1}$ ), standard error of the mean, percent catch rate change, likelihood ratio statistics $\left(\chi^{2}\right)$, and p-values between paired handline and trolling trials. $*$ denotes statistical difference at an $\alpha$ of 0.05 .

\begin{tabular}{|c|c|c|c|c|c|c|}
\hline Species & & $\begin{array}{l}\text { Mean catch rate } \\
\quad\left(\text { fish } \mathrm{hr}^{-1}\right)\end{array}$ & SE & $\%$ Change & $\chi^{2}$ & p-value \\
\hline S. tumbil & $\begin{array}{l}\text { Handline } \\
\text { Trolling }\end{array}$ & $\begin{array}{l}0.11 \\
0.08\end{array}$ & $\begin{array}{l}0.03 \\
0.02\end{array}$ & -27.3 & 2.373 & 0.123 \\
\hline A. indicus & $\begin{array}{l}\text { Handline } \\
\text { Trolling }\end{array}$ & $\begin{array}{l}0.21 \\
0.08\end{array}$ & $\begin{array}{l}0.08 \\
0.02\end{array}$ & -61.9 & 3.905 & $0.048^{*}$ \\
\hline S. commerson & $\begin{array}{l}\text { Handline } \\
\text { Trolling }\end{array}$ & $\begin{array}{l}0.20 \\
0.22\end{array}$ & $\begin{array}{l}0.04 \\
0.04\end{array}$ & 10.0 & 0.002 & 0.962 \\
\hline S. obtusata & $\begin{array}{l}\text { Handline } \\
\text { Trolling }\end{array}$ & $\begin{array}{l}0.09 \\
0.03\end{array}$ & $\begin{array}{l}0.04 \\
0.02\end{array}$ & -66.7 & 6.264 & $0.012 *$ \\
\hline S. jello & $\begin{array}{l}\text { Handline } \\
\text { Trolling }\end{array}$ & $\begin{array}{l}0.24 \\
0.34\end{array}$ & $\begin{array}{l}0.05 \\
0.07\end{array}$ & 41.7 & 0.006 & 0.938 \\
\hline S. commersonnianus & $\begin{array}{l}\text { Handline } \\
\text { Trolling }\end{array}$ & $\begin{array}{l}0.21 \\
0.12\end{array}$ & $\begin{array}{l}0.01 \\
0.03\end{array}$ & -42.9 & 2.517 & 0.113 \\
\hline Total catch & $\begin{array}{l}\text { Handline } \\
\text { Trolling }\end{array}$ & $\begin{array}{l}1.06 \\
0.88\end{array}$ & $\begin{array}{l}0.06 \\
0.05\end{array}$ & -17.0 & 9.442 & $0.002 *$ \\
\hline
\end{tabular}

The SIMPER analysis showed a significant difference between the two gears for captured fish, with a dissimilarity average of $23.53 \%$. The species that were responsible for the dissimilarity in catch composition were Indian threadfish, pickhandle barracuda and narrow-barred Spanish mackerel (Fig. 4).

\section{DISCUSSION}

This study is the first attempt to determine the catch efficiency between different fishing methods commonly used in the Gulf of Oman recreational pelagic fishery. This comparison provided evidence that the handline fishing method captured fish at a higher rate than trolling, but size selectivity between gears was

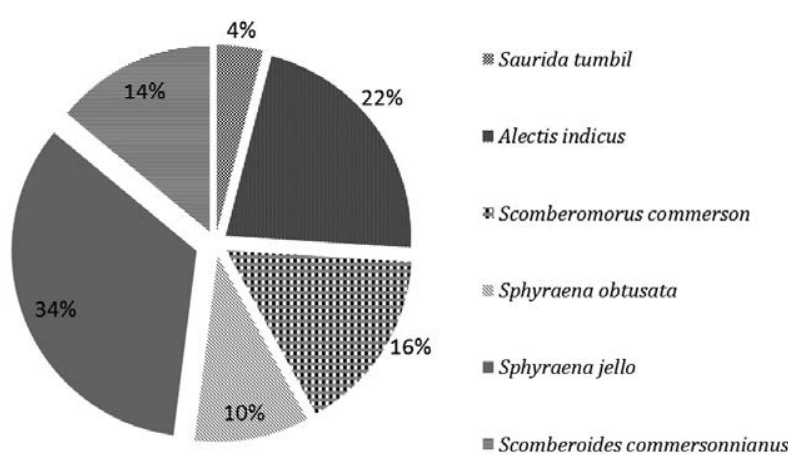

Fig. 4. - Percent dissimilarity for captured species between handline and trolling fishing gear. 
species- and fishing method-specific. Larger individuals were captured by trolling for all species except Indian threadfish, and narrow-barred Spanish mackerel showed a quadratic relationship in which small and large fish were captured more often by trolling. These results show that static (handline) and active (trolling) gears compete for many of the same pelagic species and have different impacts in terms of catch rate and size selectivity.

Fish swimming speed increases with body length (Beamish 1978, He 1993). For two of the four species investigated, larger fish were captured more often by trolling. This is likely explained by larger fish having an increased swimming capacity and having an increased ability to catch up with bait moving at the trolling speed. Indian threadfish showed the opposite relationship, smaller fish being captured more often by trolling. For narrow-barred Spanish mackerel, smaller and larger fish were captured more often by trolling, and no difference between gears was found for sizes in between. These differences are likely expressed as differences in habitat preference. While each gear fished the same length of line, a weighted handline likely fished close to the length of the line $(30 \mathrm{~m})$, whereas the trolling gears would have been higher in the water column due to the speed of the vessel. Juvenile Indian threadfish are often solitary, and found in shallow water (Fischer et al. 1990), and as adults Indian threadfish can be found in schools near the bottom (Von Westernhagen 1974). These life history traits are likely what is influencing the opposite trend of Indian threadfish being captured more often at shallow depths by the shallower-fishing trolling gear, and at depth at larger sizes by the deeper-fishing handline. Generally, narrow-barred Spanish mackerel are shallowwater predators at all sizes (Blaber et al. 1995), and the shallow-water preference in habitat for this species is likely what led it to be captured by trolling more often at multiple sizes.

In terms of capture rate, the only differences observed were for Indian threadfish, obtuse barracuda and all fish combined. Differences between Indian threadfish were likely due to the depth preferences described above, and obtuse barracuda are a very small fish relative to the others captured (maximum length $55 \mathrm{~cm}$; May and Maxwell 1986) and would probably rarely be able to catch up with the speed of a passing trolled bait. Total catch was higher due to the cumulative effects of several fish either being significantly captured more by handline gear (Indian threadfish; obtuse barracuda) or species that showed higher catches for handlines (greater lizardfish; talang queenfish).

Pelagic, predatory species were the most captured species in this study, and of these species, trolling selected for larger individuals. Narrow-barred Spanish mackerel, pickhandle barracuda and talang queenfish are all voracious marine predators, and it is not surprising that more were caught by the active fishing method (Wilson et al. 2015). Additionally, narrow-barred Spanish mackerel and pickhandle barracuda use a swift ram-feeding strike, can feed on fish larger than their jaw gape (Grubich et al. 2008), and use acute visual and olfactory senses to locate prey (Sinha 1987), all attributes that logically led to capture by trolling.

A common perception is that more active individuals tend to be more exploratory and willing to take risks and are thus more susceptible to capture (Biro and Dingemanse 2009). A number of recent studies have suggested that bigger, more active, and exploratory fish are likely more vulnerable to angling due to presumed associations with higher growth rates and metabolic needs (i.e. higher foraging rates) (Redpath et al. 2010, Uusi-Heikkila et al. 2008). Depending on what gear is being used, both passive and towed harvesting techniques might disproportionately target fish based on their behavioural attributes. The link between behaviour and the selective nature of a range of fishing gears is often emphasized (Biro and Post 2008, Løkkeborg et al. 2010, Arlinghaus et al. 2016). From an ecological and sustainable fisheries management perspective, fishers should match the appropriate fishing method to the targeted species to prevent the capture of unwanted or undersized species. For example, fishers should avoid the capture of small fish by trolling to target pickhandle barracuda and handlining to target Indian threadfish. We suggest that further research should focus on how exploited fish populations respond behaviourally to passive and towed harvesting techniques.

A number of studies have compared different gears in terms of catch rates, efficiency and size selection (Huse et al. 2000, Halliday 2002, Stergiou and Erzini 2002). Wibowo et al. (2018) reported that trolling caught substantially larger fishes than longline in southern waters of the Indian Ocean. Catch efficiency and composition were quite different between Hawaii's troll and handline fisheries (Sharma et al. 2003). With information on fishing effort, the results of comparative selectivity studies can be used to improve management by, for example, leading to a more rational and objective distribution of licences among gears (Erzini et al. 2003). Although management decisions require an integration of information on catch, effort and harvesters for both commercial and recreational sectors, little attention has been paid by policy-makers to the monitoring of recreational fisheries. There is need for timely and accurate biological, social and economic recreational fishing data to evaluate this activity (Pitcher and Hollingworth 2002, Pawson et al. 2008, Arlinghaus et al. 2010).

Many fisheries, including the Gulf of Oman pelagic fishery, use different fishing gears to target the same species. However, catching the same species with different techniques can lead to various consequences, including negative environmental and socio-economic impacts, especially for artisanal fishers. Hence, evaluating overall sustainability of these tools could offer a relevant approach to promoting healthy marine ecosystems, and to open discussions about shifting from high- to low-impact fishing practices (Fuller et al. 2008). Discards and bycatch are among the most important issues when fishing gears are compared, and little is currently known about them regarding the different fishing techniques in the Gulf of Oman. In 
order to maintain a diverse, healthy ocean, it is necessary to address the overall impact of fishing through an ecosystem-based approach (Chuenpagdee et al. 2003, Arlinghaus et al. 2016).

Factors causing variation in the vulnerability of different species and size groups to different fishing gear are important for the development of optimal harvesting strategies and the rational use of living resources (Erzini et al. 2003). Catch rates, catch composition and length frequency distributions are affected by the type and size of hooks (Patterson et al. 2012, Garner et al. 2014), catch strategy (Bjordal and Løkkeborg 1996) and bait (Moreno et al. 1992, Eighani et al. 2018). However, further research will be required to investigate the effect of hook and bait type on the Gulf of Oman pelagic fishery. Based on our results, the difference in size selectivity and catch rate between handline and trolling fishing gear can improve the fishing strategy and lead to a more conservation-oriented management of the fishery.

\section{ACKNOWLEDGEMENTS}

We thank Ted Castro-Santos and Andre Barany Ruiz for providing the Spanish abstract of the paper. We are also grateful to local commercial fishers for their help in collecting the fish used in this study.

\section{REFERENCES}

Al-Hosni A.H.S., Siddeek S.M. 1999. Growth and mortality of the narrow-barred Spanish mackerel, Scomberomorus commerson (Lacepède), in Omani waters. Fish. Manage. Ecol. 6: 145-160. https://doi.org/10.1046/j.1365-2400.1999.00134.x

Arlinghaus R., Cooke S., Cowx I. 2010. Providing context to the global code of practice for recreational fisheries. Fish. Man. Ecol. 17:146-156. https://doi.org/10.1111/j.1365-2400.2009.00696.x

Arlinghaus R., Laskowski K.L., Alós J., et al. 2016. Passive gearinduced timidity syndrome in wild fish populations and its potential ecological and managerial implications. Fish Fish. 18: 360-373. https://doi.org/10.1111/faf.12176

Bates D., Maechler M., Bolker B., et al. 2013. lme4: Linear mixedeffects models using Eigen and S4. R package version 1.0-5. Available at http://CRAN.R-project.org (July 2018).

Bayse S.M., Rillahan C.B., Jones N.F., et al. 2016. Evaluating a large-mesh belly window to reduce bycatch in silver hake (Merluccius bilinearis) trawls. Fish. Res. 174: 1-9. https://doi.org/10.1016/j.fishres.2015.08.022

Bayse S.M., Pol M.V., Walsh M., et al. 2017. Design and test of a grid to reduce bycatch in the longfin inshore squid (Doryteuthis pealeii) trawl fishery. J. Appl. Ichthyol. 33: 898-906. https://doi.org/10.1111/jai.13381

Beamish F.W.H. 1978. Swimming capacity. In: Hoar W.S., Randall D.J. (eds), Locomotion. Fish Physiol. 7: 101-187. https://doi.org/10.1016/S1546-5098(08)60164-8

Biro P.A., Dingemanse N.J. 2009. Sampling bias resulting from animal personality. Trends Ecol. Evol. 24: 66-67. https://doi.org/10.1016/j.tree.2008.11.001

Biro P.A., Post J.R. 2008. Rapid depletion of genotypes with fast growth and bold personality traits from harvested fish populations. Proc. Natl. Acad. Sci. 105: 2919-2922. https://doi.org/10.1073/pnas.0708159105

Bjordal A., Løkkeborg S. 1996. Longlining. Wiley-Blackwell, Oxford, $156 \mathrm{pp}$.

Blaber S.J.M., Brewer D.T., Salini J.P. 1995. Fish communities and the nursery role of the shallow inshore waters of a tropical bay in the Gulf of Carpentaria, Australia. Estuar. Coast. Shelf Sci. 40: $177-193$.

https://doi.org/10.1016/S0272-7714(05)80004-6
Chuenpagdee R., Morgan L.E., Maxwell S.M., et al. 2003. Shifting gears: assessing collateral impacts of fishing methods in US waters. Front. Ecol. Environ. 1: 517-524.

Eighani M., Paighambari S.Y., Herrmann B., et al. 2018. Effect of bait type and size on catch efficiency of narrow-barred Spanish mackerel (Scomberomorus commerson) in the Persian Gulf handline fisheries. Fish. Res. 199: 32-35. https://doi.org/10.1016/j.fishres.2017.11.023

Erzini K, Concalves J.M.S., Bentes L., et al. 2003. Quantifying the roles of competing static gears: comparative selectivity of longlines and monofilament gill nets in a multi-species fishery of the Algarve (southern Portugal). Sci. Mar. 67: 341-352. https://doi.org/10.3989/scimar.2003.67n3341

FAO. 2016. The State of World Fisheries and Aquaculture 2016. Contributing to food security and nutrition for all. Rome. 200 pp.

Fauconnet L., Trenkel V.M., Morandeau G., et al. 2015. Characterizing catches taken by different gears as a step towards evaluating fishing pressure on fish communities. Fish. Res. 164: 238-248. https://doi.org/10.1016/j.fishres.2014.11.019

Fischer W., Sousa I., Silva C., et al. 1990. Fichas FAO de identificaçao de espécies para actividades de pesca. Guia de campo das espécies comerciais marinhas e de águas salobras de Moçambique. Publicaçao preparada em collaboraçao com o Instituto de Investigaçao Pesquiera de Moçambique, com financiamento do Projecto PNUD/FAO MOZ/86/030 e de NORAD. FAO, Roma.

Fuller S.D., Picco C., Ford J., et al. 2008. How We Fish Matters: Addressing the Ecological Impacts of Canadian Fishing Gear. Ecology Action Centre, Vancouver, 28 pp.

Garner S., Patterson W., Porch C.E., et al. 2014. Experimental assessment of circle hook performance and selectivity in the northern Gulf of Mexico recreational reef fishery. Mar. Coast. Fish. 6: 235-246. https://doi.org/10.1080/19425120.2014.952463

Grubich J.R., Rice A.N., Westneat M.W. 2008. Functional morphology of bite mechanics in the great barracuda (Sphyraena barracuda). Zoology 111: 16-29. https://doi.org/10.1016/j.zool.2007.05.003

Halliday R.G. 2002. A comparison of size selection of Atlantic cod (Gadus morhua) and haddock (Melanogrammus aeglefinnus) by bottom longlines and otter trawls. Fish. Res. 57: 63-73. https://doi.org/10.1016/S0165-7836(01)00336-8

He P. 1993. Swimming speeds of marine fish in relation to fishing gears. ICES Mar. Sci. Symp. 196: 183-189.

Herrmann B., Eighani M., Paighambari S.Y., et al. 2018. Effect of Hook and Bait Size on Catch Efficiency in the Persian Gulf Recreational Fisheries. Mar. Coast. Fish. 10: 314-324. https://doi.org/10.1002/mcf2.10031

Holst R., Revill A. 2009. A simple statistical method for catch comparison studies. Fish. Res. 95: 254-259. https://doi.org/10.1016/j.fishres.2008.09.027

Hovgård H., Riget F.F. 1992. Comparison of longline and trawl selectivity in cod surveys off West Greenland. Fish. Res. 13: 323-333. https://doi.org/10.1016/0165-7836(92)90085-8

Huse I., Gundersen A.C., Nedreaas K.H. 1999. Relative selectivity of Greenland halibut (Reinhardtius hippoglossoides, Walbaum) by trawls, longlines and gillnets. Fish. Res. 44: 75-93. https://doi.org/10.1016/S0165-7836(99)00041-7

Huse I., Løkkeborg S., Soldal A.V. 2000. Relative selectivity in trawl, longline and gillnet fisheries for cod and haddock. ICES J. Mar. Sci. 57: 1271-1282. https://doi.org/10.1006/jmsc.2000.0813

Iran Fisheries Organization (IFO). 2017. Fisheries yearbook. IFO, Tehran.

Jones C.M., Pollock K.H. 2012. Recreational angler survey methods: Estimation of effort, harvest, and released catch. In: Zale A.V., Parrish D.L., Sutton T.M (eds). Fisheries Techniques, Bethesda, MD, 883-919 pp.

Løkkeborg S., Bjordal A. 1992. Species and size selectivity in longline fishing: a review. Fish. Res. 13: 311-322. https://doi.org/10.1016/0165-7836(92)90084-7

Løkkeborg S., Fernö A., Humborstad O.B. 2010. Fish behavior in relation to longlines. In: He P. (ed), Behavior of marine fishes: capture processes and conservation Challenges. Wiley-Blackwell, Ames, IA, 105-141 pp. https://doi.org/10.1002/9780813810966.ch5

May J.L., Maxwell J.G.H. 1986. Trawl fish from temperate waters of Australia. CSIRO Division of Fisheries Research, Tasmania. $492 \mathrm{pp}$. 
McPhee D.P., Leadbitter D., Skilleter G.A. 2002. Swallowing the bait: Is recreational fishing in Australia ecologically sustainable? Pac. Cons. Biol. 8: 40-51. https://doi.org/10.1071/PC020040

Mohri M., Tanoue H., Okawa T., et al. 2017. Report of Trolling Fishing Practice (T/V Tenyo-Maru's 242nd voyage) in Japan Sea. J. Natl. Fish. Univ. 65: 267-272.

Moreno S., Pol J., González C. 1992. Selection properties of the baited hooks used in the Cuban long-line fishery of Campeche bank, Gulf of Mexico. Naga ICLARM Q 15: 28-29.

National Research Council (NRC). 1988. Fisheries Technologies for Developing Countries. The National Academies Press. Washington DC. $176 \mathrm{pp}$ https://doi.org/10.17226/1024

Niamaimandi N., Kaymaram F., Hoolihan J.P. et al. 2015. Population dynamics parameters of narrow-barred Spanish mackerel, Scomberomorus commerson (Lacèpéde, 1800), from commercial catch in the northern Persian Gulf. Fish. Res. 4: 666-672. https://doi.org/10.1016/j.gecco.2015.10.012

Otway N.M., Craig J.R. Upston J.M. 1996. Gear-dependent size selection of snapper, Pagrus auratus. Fish. Res. 28: 119-132. https://doi.org/10.1016/0165-7836(96)00500-0

Paighambari S.Y., Eighani M. 2017. Study on different hook and bait types in the Persian Gulf hand line fishery: optimization and development. Aqua. Liv. Res. 30: 23. https://doi.org/10.1051/alr/2017007

Patterson W.F., Porch C.E., Tarnecki J.H., et al. 2012. Effect of circle hook size on reef fish catch rates, species composition, and selectivity in the northern Gulf of Mexico recreational fishery. Bull. Mar. Sci. 88: 647-665. https://doi.org/10.5343/bms.2011.1086

Pawson M.G., Glenn H., Padda G. 2008. The definition of marine recreational fishing in Europe. Mar. Pol. 32: 339-350. https://doi.org/10.1016/j.marpol.2007.07.001

Pitcher T.J., Hollingworth C. 2002. Recreational Fisheries, Ecological, Economic and Social Evaluation. Fish Aqua. Res. Series 8, Blackwell Science. 271 pp. https://doi.org/10.1002/9780470995402

R Development Core Team. 2009. R: A language and environment for statistical computing. Vienna, Austria: R Foundation for Statistical Computing. Retrieved from http://www.R-project. org. Accessed on 14 Aug 2018.

Redpath T.D., Cooke S.J., Suski C.D., et al. 2010. The metabolic and biochemical basis of vulnerability to recreational angling after three generations of angling-induced selection in a teleost fish. Can. J. Fish. Aquat. Sci. 67: 1983-1992.
https://doi.org/10.1139/F10-120

Santos M.N., Gasper M.B., Monteiro C.C., et al. 2002. Gill net and longline catch comparisons in a hake fishery: the case of southern Portugal. Sci. Mar. 66: 433-441. https://doi.org/10.3989/scimar.2002.66n4433

Sharma R., Pradhan N.C., Leung P. 2003. Technological and economic interrelationships in Hawaii's troll and handline fisheries. N. Am. J. Fish. Manage. 23: 869-882. https://doi.org/10.1577/M01-189

Sinha R.K. 1987. Morphology and anatomy of the olfactory organs of a marine fish Sphyraena jello (C.). Folia Morphol. (Praha) 35: 202-205.

Stergiou K.I., Erzini K. 2002. Comparative fixed gear studies in the Cyclades (Aegean Sea): size selectivity of small-hook longlines and monofilament gill nets. Fish. Res. 58: 25-40. https://doi.org/10.1016/S0165-7836(01)00363-0

Stergiou K.I., Moutopoulos D.K., Erzini K. 2002. Gill net and longlines fisheries in Cyclades waters (Aegean Sea): species composition and gear competition. Fish. Res. 57: 25-37. https://doi.org/10.1016/S0165-7836(01)00334-4

Uusi-Heikkila S., Wolter C., Klefoth T., et al. 2008. A behavioral perspective on fishing-induced evolution. Trends Ecol. Evol. 23: 419-421. https://doi.org/10.1016/j.tree.2008.04.006

Valdimarsson G., James D. 2001. World fisheries - Utilization of catches. Ocean Coast. Man. 44: 619-633. https://doi.org/10.1016/S0964-5691(01)00072-2

Venables W.N., Ripley B.D. 2002. Modern applied statistics with S, 4th ed. Springer, New York. 497 pp. https://doi.org/10.1007/978-0-387-21706-2

Von Westernhagen H. 1974. Observations on the natural spawning of Alectis indicus (Rüppell) and Caranx ignobilis (Forsk.) (Carangidae). J. Fish Biol. 6: 513-516. https://doi.org/10.1111/j.1095-8649.1974.tb04567.x

Welcomme R. 2001. Inland fisheries: Ecology and Mananagement. Blackwell Science, Oxford. 358 pp. https://doi.org/10.1002/9780470995693

Wibowo B., Sondita M.F.A., Iskandar B.H., et al. 2018. Size composition of tuna from purse seiner, longliner, trolling line and fishing lines in southern waters of Java, Indian Ocean, Indonesia. AACL Bioflux 11: 203-210.

Wilson A.D.M., Brownscombe J.W., Sullivan B., et al. 2015. Does angling technique selectively target fishes based on their behavioural type? PLoS ONE 10: e0135848. https://doi.org/10.1371/journal.pone.0135848 